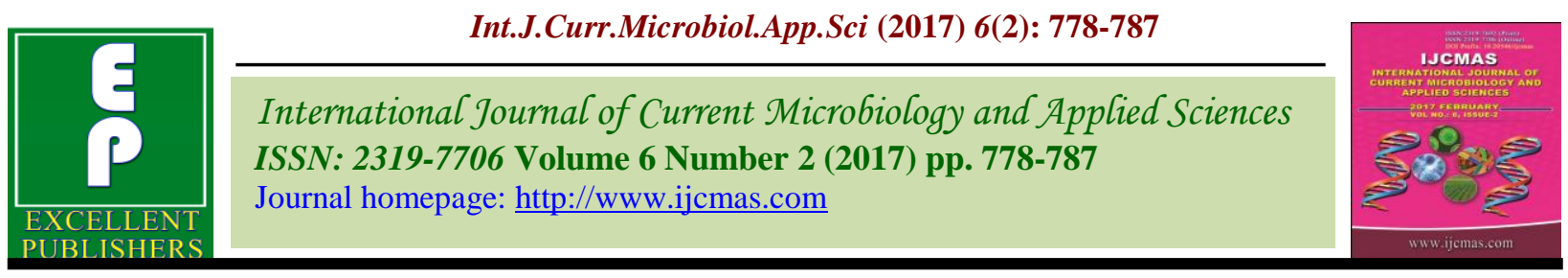

Original Research Article

http://dx.doi.org/10.20546/ijcmas.2017.602.086

\title{
Correlation between Body Mass Index and Gut Microbiota in Adults
}

\author{
Sally M. Saber ${ }^{1}$, *Hala B. Othman ${ }^{1}$, Sherin EIMasry ${ }^{1}$, \\ Alaa Magdy ${ }^{1}$ and Howayda F. Zidan² \\ ${ }^{1}$ Clinical Pathology Department, Faculty of Medicine, Ain Shams University, Egypt \\ ${ }^{2}$ Department of Rheumatology and Rehabilitation, Faculty of Medicine, \\ Ain Shams University, Egypt \\ \#Corresponding author
}

\section{A B S T R A C T}

Keywords

Obesity,

Lactobacillus reuteri,

Lactobacillus

paracasei,

Lactobacillus

plantarum, E. coli,

Probiotics, Prebiotics

and synbiotics.

Article Info

Accepted:

18 January 2017

Available Online:

10 February 2017
Gut microbiota has been proposed as a new environmental risk factor responsible for obesity. So, the aim of this study was to assess the gut microbiota profile, with special consideration to Lactobacilli, E. coli and S. aureus viable bacterial count (VBC) in (CFU/gm) and their association with body mass index (BMI) and obesity using quantitative stool culture. This study was conducted on 100 individuals; 74 with disturbed BMI who were divided into subgroups, with no other associated comorbidities and 26 healthy average weight volunteers. Fresh stool samples were collected and cultured directly on MacConkey, xylose lysine deoxycholate, Blood and Man-Rogoza Sharpe agar and quantitatively with serial dilutions $\left(10^{-2}-10^{-9}\right)$ in sterile normal saline. S. aureus was not isolated in any group, while, Lactobacilli and E. coli were isolated from all groups. Lactobacilli have a significant low VBC in obese and the highest VBC in the normal weight group showing a negative correlation with BMI. While, E. coli had a significantly high VBC in obese and the lowest in the underweight group showing a positive correlation with BMI. In conclusion, low Lactobacilli $\mathrm{VBC}$ and high E. coli $\mathrm{VBC}$ are significantly related to increased $\mathrm{BMI}$ and thus obesity.

\section{Introduction}

The rapidly growing prevalence of obesity among children, adolescents and adults and the associated metabolic disorders has become a global health problem (Xiao et al., 2014).

Body mass index (BMI) is a good measure of obesity. Increased BMI is an established risk factor for many diseases; including, hypertension, ischemic heart disease, stroke, diabetes mellitus, respiratory disorders, and cancer of the large intestine, kidney, endometrium, and postmenopausal breast. It is also related to a significantly increased mortality (Whitlock et al., 2009).

Obesity is a complex condition influenced by many factors as Genetic, endocrinal and environmental factors (Xiao et al., 2014). Gut microbiota has been proposed as a new environmental risk factor responsible for the weight gain and the altered energy metabolism that accompanies the obese state. The gut microbiota enables enzymatic 
digestion of nondigestible polysaccharides producing absorbable monosaccharides; and it activates lipoprotein lipase on intestinal epithelium, which causes rapid absorption of glucose and fatty acids, contributing to the fat mass expansion and weight gain (Musso et al., 2011). Many studies in both human subjects and experimental animals showed a significant association between the increase of some bacterial groups and obesity [(Bäckhed et al., 2004); (Ley et al., 2005); (Ley et al., 2006); (Turnbaugh et al., 2009) and (Cani et al., 2008)]. Some studies found that Lactobacillus genus was the most predominant type of microbiota in stool of overweight and obese persons (Armougom et al., 2006); (Ignacio et al., 2016), while other studies linked overweight and obesity to Enterobacteriaceae, specifically E. coli (Santacruz et al., 2010 and Karlsson et al., 2011) and S. aureus (Santacruz et al., 2010). Also, elevated proportion of Firmicutes (Lactobacilli) and reduced population of Bacteroidetes (Bacteroides) has been associated with obesity (Angelakis et al., 2012). Moreover, gut microbiota composition at the species level even in the same genus is related to body weight and obesity as Lactobacillus reuteri is found more frequently in obese subjects whereas, Lactobacillus paracasei and Lactobacillus plantarum are significantly associated with lean status (Million et al., 2012). Although these faecal microflora variability at the species level is detected by molecular tools based on $16 \mathrm{~s}$ rDNA sequence similarities such as fluorescent in-situ hybridization (FISH) and denaturing gradient gel electrophoresis (DGGE) (Sharma et al., 2012). However, these methods are costly, tedious, and measure even non-viable organisms (Sieuwerts et al., 2008).

So, the aim of this study was to assess the gut microbiota profile, with special consideration to Lactobacilli, E. coli and S. aureus viable bacterial count (VBC) in (CFU/gm)and their association with body mass index (BMI) and obesity using quantitative stool culture.

\section{Materials and Methods}

This study was conducted on 100adults; 74 with disturbed BMI with no other associated co morbidities who were selected randomly from obesity outpatient Clinic of Ain Shams University Hospitals and 26 healthy average weight volunteers were included as control group matched for age and gender over a study period from September 2013 to February 2014. Confidentiality of information was maintained and consent was taken from each participant.

\section{Exclusion criteria for the included subjects (Million et al., 2013)}

Adults less than 18 years old, history of cancer colon, presence of inflammatory bowel disease, an acute or chronic diarrhea in the previous 4 weeks before taking the stool sample, antibiotic, prebiotic and probiotic administration of a period less than one month before faecal sampling, familial obesity, patients with associated co-morbidities as (Diabetes mellitus, hypertension, cardiovascular stroke, chronic liver disease, and renal diseases), patients with dyslipidaemia, hormonal or endocrinal disturbance as (Thyroid dysfunction, Cushing syndrome, Growth hormone insufficiency).

Clinical history was taken and laboratory investigations were done to exclude the associated co-morbidities. Anthropometric measurements [weight, height, waist circumference (WC), hip circumference (HC) and waist to hip ratio (WC/HC)] using measuring tape and scale were assessed.

The studied groups were divided according to Million et al., (2013) into subgroups 
according to BMI that was defined as weight/ (height) ${ }^{2}$ as follows:

(1) Obese group: (29) patients who were subdivided into

- Morbidly obese (50 > BMI > 40)

Six patients; their age ranged from $30-$ 40 with mean $36.000+3.950$.

- Obese group (40 > BMI > 30)

Twenty-three patients; their age ranged from 19-53 with mean 36.522 +11.016 .

(2) Overweight group: (23) patients

Twenty-three patients $(30>$ BMI >25); their age ranged from 19-47 with mean $33.522+$ 8.409 .

(3) Average weight or lean group (control group): (26) patients

Twenty-six patients $(25>$ BMI $>19)$, their age ranged from 19-54 with mean 31.192+9.148.

(4) Underweight group (22) patients

Twenty-two patients (BMI <19), their age ranged from $19-45$ with mean $29.000+6.726$.

\section{Stool sample collection and processing}

Fresh stool samples were collected in sterile screw caped containers and delivered to The Central Microbiology Laboratory of Ain Shams University Hospitals for qualitative and quantitative culture.

Qualitative and quantitative culture for viable bacterial count (VBC) was done according to Sharma et al., (2012).

Qualitative culture: Part of the stool were cultured directly on MacConkey agar media plates $\left(\mathrm{Oxoid}^{\circledR}, \mathrm{UK}\right)$; to identify the microbial growth pattern of gram negative bacteria for each patient, on Xylose lysine deoxycholate (XLD) agar media plates $\left(\mathrm{Oxoid}^{\circledR}, \mathrm{UK}\right)$ to exclude Shigella and carrier state of Salmonella, on Blood agar plates (Oxoid ${ }^{\circledR}$, UK) for isolation of gram positive bacteria, and on Man-Rogoza Sharpe agar media (MRs) $\quad\left(\right.$ Oxoid $^{\circledR}, \quad$ UK) for isolation of Lactobacillus species.

\section{Quantitative culture for VBC (CFU/gm stool)}

Approximately one gram of each stool sample was transferred to one $\mathrm{mL}$ sterile normal saline and mixed thoroughly. Stool samples were serially diluted $\left(10^{-2}-10^{-9}\right)$.Ten $\mu \mathrm{L}$ from each dilution was plated using the quadrant technique on Man-Rogoza Sharpe agar media (MRs) agar $\left(\mathrm{Oxoid}^{\circledR}\right.$, UK) for isolation and enumeration of VBC of Lactobacillus species, incubated anaerobically at $37^{\circ} \mathrm{C}$ for $72-$ hoursand on blood agar for isolation and enumeration of VBC of $S$. aureus, and $E$. coli which incubated aerobically for 48-hours at $37^{\circ} \mathrm{C}$.

All colonies of different morphology grown on XLD, MacConkey and from the highest dilution of (MRs) and blood agar were identified using conventional biochemical methods. The viable bacterial count of Lactobacilli, E. coli and S. aureus was calculated from the highest dilution and expressed as $\mathrm{CFU} / \mathrm{gm}$.

\section{Statistical analysis}

Non-numerical data were expressed as numbers (\%). Chi-square was used to compare between two variables in qualitative data. Linear Correlation coefficient was used for detection of correlation between two quantitative variables in one group. ANOVA test was used for comparison among different 
times in the same group in quantitative data. Kruskal-Wallis test is a nonparametric equivalent to one-way ANOVA used to determine if there are statistically significant differences between two or more groups of an independent variable on a continuous or ordinal dependent variable. All the analyses were performed with commercially available software (SPSS version 17, SPSS, Inc., Chicago, IL, USA)

\section{Results and Discussion}

\section{The demographics and Anthropometric measurements}

The demographics and Anthropometric measurements of the studied groups were shown in table 1 .

In our study, the age and gender were not statistically different between all studied groups. A significant difference in height and $\mathrm{WC} / \mathrm{HC}$ ratio was found $(\mathrm{P}<0.05)$ among the studied groups; with the highest height in the underweight group (mean 1.682+0.122), and the lowest height in the morbidly obese group (mean 1.578+0.056). While, the lean group had the highest $\mathrm{WC} / \mathrm{HC}$ ratio, (mean $0.848 \pm 0.037$ ) and the morbidly obese group had the lowest ratio, (mean 0.793+0.053). Also, there was a highly significant difference among the studied groups regarding $\mathrm{WC}$ and HC $(\mathrm{P}<0.001)$; being the lowest in the underweight group, (mean 71.000+1.380, $88.182+4.216)$ respectively. While both circumferences were the highest in the morbidly obese group (mean 92.833+3.430, $117.333+5.785$ ) respectively.

\section{Distribution of gut flora among the studied groups}

In our study, $S$. aureus was not isolated in any of the studied groups. The most abundant genera in all groups were E. coli $(100 \%)$, and
Lactobacilli (97\%).The gut microbiota had the greatest genera diversity in the low BMI groups (normal and underweight); E. coli (100\%), Lactobacilli spp. (97.91\%), Citrobacter spp. (58.33\%), Enterobacter spp. (16.66\%), Morganella spp. (12.5\%), Acinetobacter spp. (10.41\%), and Providencia spp. (10.41\%). The diversity decreased as the BMI increased (overweight, obese and morbid obese); E. coli (100\%), Lactobacilli spp. (97.15\%), Citrobacter spp. (57.69\%), Acinetobacter spp. (9.62\%), Morganella spp. (5.76\%), and Serratia spp. (3.85\%). The prevalence of Citrobacter spp. was significantly higher in morbidly obese group $(\mathrm{P}<0.05)$ while, Enterobacter spp. Were present only in low BMI groups (normal weight and underweight $) \quad(\mathrm{P}<0.05)$. Acinetobacter spp. prevalence was higher in obese and underweight groups, with no significant difference $(\mathrm{P}>0.05)$. Although Lactobacilli and E. coli were isolated from all groups with higher prevalence in normal and overweight groups, however this result was statistically insignificant ( $>>0.05)$ (Table 2). In agreement with our study Chiu et al., (2014) found that bacterial communities in Taiwanese 45 normal stool samples $(\mathrm{BMI} \leq$ 24) had a greater genera richness than those in 36 case samples (with a BMI $\geq 27$ ). The supervised analysis showed that, the most abundant genera of bacteria in normal samples were Bacteroides (27.7\%), Prevotella (19.4\%), Escherichia (12\%), Phascolarctobacterium (3.9\%), and Eubacterium (3.5\%). The most abundant genera of bacteria in case samples were Bacteroides (29\%), Prevotella (21\%), Escherichia (7.4\%), Megamonas (5.1\%), and Phascolarcto bacterium (3.8\%). Also, they found that, Acinectobacter spp. was positively correlated with obesity. The genera of Citrobacter, Tatumella, and Acinetobacter exhibited significant differences in both presence and proportions between normal and case samples. Their findings may be resulted 
from their categorization of the studied groups into case and control groups without any exclusion criteria, associated comorbidities or hormonal disturbance that may affect the diversity of gut microbiota. Moreover, anaerobes were isolated successfully in their study in contrast to this study which focused mainly on aerobes and facultative anaerobes. Also, they used sequencing of PCR products which may detect dead bacteria that do not express their metabolic effect (Sepp et al., 2013). While, Xiao et al, (2014) found a positive correlation between Citrobacter and BMI $\geq 28 \mathrm{Kg} \mathrm{m}^{-2}$. Million et al., (2013) who categorize their study subjects into four groups; group I: obese subjects (BMI> $30 \mathrm{Kg} \mathrm{m}^{-2}$ ), group II: overweight subjects (BMI $>25$ and $<30 \mathrm{Kg} \mathrm{m}^{-}$ ${ }^{2}$ ), group III: lean subjects (BMI $>19$ and $<25$ $\mathrm{Kg} \mathrm{m}{ }^{-2}$ ) and group IV: anorexic subjects (BMI $<19 \mathrm{Kg} \mathrm{m}^{-2}$ ) found that, the prevalence of Lactobacillius was higher in obese compared to lean group $(\mathrm{p}=0.06)$ and a higher frequency of Lactobacillus in individuals with $\mathrm{BMI}>25 \mathrm{Kg} \mathrm{m}^{-2}$ vs $\mathrm{BMI}<25$ $\mathrm{Kg} \mathrm{m}^{-2}(\mathrm{p}=0.06)$, with a threefold increase in $L$. reuteri occurrence in obese patients compared with lean subjects $(\mathrm{P}=0.01)$, and a threefold increase between individuals with BMI > $25 \mathrm{Kg} \mathrm{m}^{-2}$ compared to individuals with $\mathrm{BMI}<25 \mathrm{Kg} \mathrm{m}^{-2} \quad(\mathrm{P}=0.001)$. Also, they found that, the prevalence of $E$. coli was lower in obese compared with lean group $(\mathrm{p}=$ 0.006) and the presence of Bacteroidetes was associated with the absence of obesity $(\mathrm{OR}=$ $0.51 ; \mathrm{P}=0.02$ ) however anaerobes were not assessed in this study.

\section{Viable bacterial count of Lactobacilli in the studied groups}

In our study, Lactobacilli VBC showed significant difference among the studied groups $(\mathrm{P}=0.006)$, with the highest concentration found in the normal weight group with a median of $\left(6.3 \times 10^{9} \mathrm{CFU} / \mathrm{gm}\right)$ and the lowest concentration was in the Obese $\left(8 \times 10^{8} \mathrm{CFU} / \mathrm{gm}\right)$ (Table 3$)$. In contrast to our results, Armougom et al., (2006) and Million et al., (2012) found that Lactobacillus spp. concentration was significantly higher in obese subjects than lean control by quantitative PCR (qPCR). Also, Million et al., (2013), found that, Lactobacillus concentration was higher in obese patients compared with lean patients $(\mathrm{P}<0.05)$ and in individuals with $\mathrm{BMI}>25 \mathrm{Kg} \mathrm{m}^{-2}$ vs individuals with $\mathrm{BMI}<25 \mathrm{Kg} \mathrm{m}^{-2}$. But Million et al., (2012) found that, Lactobacillus spp. concentration by culture on Lactobacillus specific culture was not significantly different between obese and control subjects median (4.15 vs. 5.2 $\log 10$ $\mathrm{CFUml}^{-1}$ ) respectively. However, our results could be explained by Million et al., (2012) who found that, not only the concentration of Lactobacilli is the only discriminator between lean and obese individuals but also, the species did. They showed that Lactobacillus paracasei and Lactobacillus plantarum had a significant higher level in normal weight by culture, and qPCR, however, only Lactobacillus paracasei was significantly associated with lean status (odds ratio $=0.79$; $\mathrm{p}=0.03$ ), while Lactobacillus reuteri had a significant higher level in obese subjects by qPCR not by culture. Also, Million et al., (2013) showed that Lactobacillus reuteri concentration was positively correlated with BMI.

Viable bacterial count of $E$. coli in the studied groups

Also, in our study, the E. coli VBC was significantly different among different groups $(\mathrm{P}<0.001)$ being the highest in obese group $\left(2.4 \times 10^{10} \mathrm{CFU} / \mathrm{gm}\right)$, and the lowest in the

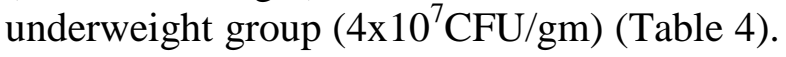
Similarly, Santacruz et al., (2010) found that, Enterobacteriaceae $(\mathrm{P}=0.001), \quad$ E. coli $(\mathrm{P}=0.005)$ and Staphylococcus $(\mathrm{P}=0.006)$ 
numbers by qPCR were lower in normalweight $\mathrm{BMI}<25 \mathrm{Kg} \mathrm{m}^{-2}$ than in overweight BMI $>25 \mathrm{Kg} \mathrm{m}^{-2}$ pregnant women. In contrast, Million et al., (2013) found that, the concentration of $E$. coli was lower in obese compared with lean group $(\mathrm{P}=0.02)$, anorexic $(\mathrm{P}=0.001)$ and overweight individuals $(\mathrm{P}=$ 0.012 ) and in individuals with BMI > 25 vs. < $25 \mathrm{Kg} \mathrm{m} \mathrm{m}^{-2}$ showing that, a higher concentration of $E$. coli was associated with a lower BMI.

Correlation between anthropometric measures and VBC of both Lactobacilli and E. coli

There was a significant positive correlation between Lactobacilli VBC and height $\mathrm{r}=0.221$, and a significant negative correlation between VBC of Lactobacilli and
BMIr=0.235 (Fig. 1). On the other hand there was a significant positive correlation between VBC of E. coli and BMI r=0.002 (Fig. 2), weight $r=0.008$, waist circumference $r=0.002$, hip circumference $r=0.016$. On the contrary to our study Million and his co-workers (2013) found that, higher concentration of $E$. coli was associated with lower BMI, while, higher concentration of Lactobacillus reuteri was associated with higher BMI.

To our knowledge, these results provide new insights into the correlation between gut microbiota and the rising trend in obesity in our population as this issue will be of great importance in the management of this growing worldwide problem and with special considering of the flourishing market of probiotics (Million et al., 2012).

Table.1 The studied participants' characteristics and demographics

\begin{tabular}{|c|c|c|c|c|c|}
\hline $\begin{array}{l}\text { Participant } \\
\text { characteristics }\end{array}$ & $\begin{array}{c}\text { Under weight } \\
\text { BMI }<19 \\
(n=22) \\
\text { Mean } \pm 2 \text { SD }\end{array}$ & $\begin{array}{c}\text { Normal weight } \\
\begin{array}{c}25> \\
\text { BMI }>19\end{array} \\
(n=26) \\
\text { Mean } \pm 2 \text { SD }\end{array}$ & $\begin{array}{c}\text { Over weight } \\
30>\text { BMI } \\
>25 \\
(n=23) \\
\text { Mean } \pm 2 \text { SD }\end{array}$ & $\begin{array}{c}\text { Obese } \\
40>\underset{(n=23)}{\text { BMI }}>30 \\
\text { Mean } \pm 2 \text { SD }\end{array}$ & $\begin{array}{c}\begin{array}{c}\text { Morbid obesity } \\
50\end{array} \\
>\text { BMI }>40 \\
(n=6) \\
\text { Mean } \pm 2 \text { SD }\end{array}$ \\
\hline Age (year) & $\begin{array}{l}19-45 \\
(29.000 \pm 6.726)\end{array}$ & $\begin{array}{l}19-54 \\
(31.192 \pm 9.148)\end{array}$ & $\begin{array}{l}19-47 \\
(33.522 \pm 8.409)\end{array}$ & $\begin{array}{l}19-53 \\
(36.522 \pm 11.016)\end{array}$ & $\begin{array}{l}30-40 \\
(36.000 \pm 3.950)\end{array}$ \\
\hline Weight $(\mathrm{kg})$ & $\begin{array}{l}38-62 \\
(50.409 \pm 6.464)\end{array}$ & $\begin{array}{l}49-77 \\
(59.365 \pm 8.219)\end{array}$ & $\begin{array}{l}57-102 \\
(79.478 \pm 13.36)\end{array}$ & $\begin{array}{l}67-120 \\
(88.348 \pm 12.662)\end{array}$ & $\begin{array}{l}99-123 \\
(109.5 \pm 8.888)\end{array}$ \\
\hline Height (meters) & $\begin{array}{l}1.49-1.9 \\
(1.682 \pm 0.122)\end{array}$ & $\begin{array}{l}1.49-1.88 \\
(1.628 \pm 0.104)\end{array}$ & $\begin{array}{l}1.47-1.88 \\
(1.680 \pm 0.128)\end{array}$ & $\begin{array}{l}1.47-1.8 \\
(1.593 \pm 0.087)\end{array}$ & $\begin{array}{l}1.53-1.68 \\
(1.578 \pm 0.056) \\
\end{array}$ \\
\hline $\begin{array}{l}\text { Waist } \\
\text { circumference } \\
(\mathrm{cm})\end{array}$ & $\begin{array}{l}68-74 \\
(71.000 \pm 1.380)\end{array}$ & $\begin{array}{l}70-90 \\
(79.885 \pm 5.743)\end{array}$ & $\begin{array}{l}77-102 \\
(83.826 \pm 5.734)\end{array}$ & $\begin{array}{l}80-98 \\
(89.087 \pm 3.848)\end{array}$ & $\begin{array}{l}87-97 \\
(92.833 \pm 3.430)\end{array}$ \\
\hline $\begin{array}{l}\text { Hip } \\
\text { circumference } \\
(\mathrm{cm})\end{array}$ & $\begin{array}{l}83-99 \\
(88.182 \pm 4.216)\end{array}$ & $\begin{array}{l}80-104 \\
(94.192 \pm 5.987)\end{array}$ & $\begin{array}{l}88-110 \\
(99.435 \pm 5.106)\end{array}$ & $\begin{array}{l}92-117 \\
(106.870 \pm 7.015)\end{array}$ & $\begin{array}{l}110-123 \\
(117.333 \pm 5.785)\end{array}$ \\
\hline $\begin{array}{l}\text { Waist } \\
\text { circumference/ } \\
\text { Hip } \\
\text { circumference } \\
\text { (cm) }\end{array}$ & $\begin{array}{l}0.714-0,881 \\
(0.807 \pm 0.040)\end{array}$ & $\begin{array}{l}0.777-0.917 \\
(0.848 \pm 0.037)\end{array}$ & $\begin{array}{l}0.709-1.000 \\
(0.845 \pm 0.063)\end{array}$ & $\begin{array}{l}0.714-0.922 \\
(0.837 \pm 0.060)\end{array}$ & $\begin{array}{l}0.719-0.864 \\
(0.793 \pm 0.053)\end{array}$ \\
\hline
\end{tabular}


Table.2 Distribution of fecal gut flora among the studied groups $(n=100)$

\begin{tabular}{|c|c|c|c|c|c|c|c|c|c|c|c|c|}
\hline & \multicolumn{10}{|c|}{ Groups } & \multirow{2}{*}{\multicolumn{2}{|c|}{ Chi-Square }} \\
\hline & \multicolumn{2}{|c|}{$\begin{array}{l}\text { Under weight } \\
\quad(n=22)\end{array}$} & \multicolumn{2}{|c|}{$\begin{array}{c}\text { Normal weight } \\
(n=26)\end{array}$} & \multicolumn{2}{|c|}{$\begin{array}{c}\text { Over weight } \\
(n=23)\end{array}$} & \multicolumn{2}{|c|}{$\begin{array}{l}\text { Obese } \\
(n=23)\end{array}$} & \multicolumn{2}{|c|}{$\begin{array}{c}\begin{array}{c}\text { Morbid obesity } \\
(n=6)\end{array} \\
\end{array}$} & & \\
\hline & $\mathbf{N}$ & $\%$ & $\mathbf{N}$ & $\%$ & $\mathbf{N}$ & $\%$ & $\mathbf{N}$ & $\%$ & $\mathbf{N}$ & $\%$ & $\mathrm{X}^{2}$ & P-value \\
\hline Citrobacter & 8 & 36.36 & 20 & 76.92 & 15 & 65.22 & 10 & 43.48 & 5 & 83.33 & 9.968 & $0.041 *$ \\
\hline Enterobacter & 3 & 13.64 & 5 & 19.23 & 0 & 0.00 & 0 & 0.00 & 0 & 0.00 & 9.927 & $0.042 *$ \\
\hline Morgenella & 2 & 9.09 & 4 & 15.38 & 3 & 13.04 & 0 & 0.00 & 0 & 0.00 & 4.622 & 0.328 \\
\hline Serratia & 0 & 0.00 & 0 & 0.00 & 2 & 8.70 & 0 & 0.00 & 0 & 0.00 & 6.832 & 0.145 \\
\hline Acinetobacter & 4 & 18.18 & 1 & 3.85 & 1 & 4.35 & 4 & 17.39 & 0 & 0.00 & 5.610 & 0.230 \\
\hline Provedencia & 3 & 13.64 & 2 & 7.69 & 0 & 0.00 & 0 & 0.00 & 0 & 0.00 & 6.588 & 0.159 \\
\hline E.coli & 22 & 100.00 & 26 & 100.00 & 23 & 100.00 & 23 & 100.00 & 6 & 100.00 & $\mathrm{x}$ & $\mathrm{x}$ \\
\hline Lactobacilli & 21 & 95.45 & 26 & 100.00 & 23 & 100.00 & 22 & 95.65 & 5 & 83.33 & 5.691 & 0.223 \\
\hline
\end{tabular}

Table.3 Comparison between studied groups as regards fecal Lactobacilli VBC in (CFU/gm)

\begin{tabular}{|c|c|c|c|c|c|c|}
\hline \multirow{2}{*}{ Groups } & \multicolumn{4}{|c|}{ Lactobacilli VBC (CFU/gm) } & \multicolumn{2}{|c|}{$\begin{array}{c}\text { Kruskal-Wallis } \\
\text { Test }\end{array}$} \\
\hline & Range & Median & $\begin{array}{c}\text { Interquartile } \\
\text { Range }\end{array}$ & $\begin{array}{l}\text { Mean } \\
\text { Rank }\end{array}$ & $\mathbf{X}^{2}$ & P-value \\
\hline Underweight & $1.5 \times 10^{8}-2 . \times 10^{10}$ & $2.8 \times 10^{9}$ & $1.87 \times 10^{10}$ & 56.21 & \multirow{5}{*}{14.461} & \multirow{5}{*}{0.006} \\
\hline Normal & $6 \times 10^{6}-7 \times 10^{10}$ & $6.3 \times 10^{9}$ & $3.51 \times 10^{10}$ & 61.35 & & \\
\hline Overweight & $3.5 \times 10^{6}-6.6 \times 10^{10}$ & $2.4 \times 10^{9}$ & $3.90 \times 10^{9}$ & 45.35 & & \\
\hline Obese & $2 \times 10^{7}-3.7 \times 10^{10}$ & $8 \times 10^{8}$ & $3.05 \times 10^{9}$ & 36.66 & & \\
\hline $\begin{array}{c}\text { Morbid } \\
\text { obesity }\end{array}$ & $2 \times 10^{7}-4 \times 10^{9}$ & $2 \times 10^{8}$ & $2.4 \times 10^{9}$ & 25.60 & & \\
\hline
\end{tabular}

Table.4 Comparison between studied groups as regards faecal E. coli VBC in (CFU/gm)

\begin{tabular}{|c|c|c|c|c|c|c|}
\hline \multirow{2}{*}{ Groups } & \multicolumn{4}{|c|}{ E. coli $\mathrm{VBC}(\mathrm{CFU} / \mathrm{gm})$} & \multicolumn{2}{|c|}{$\begin{array}{c}\text { Kruskal-Wallis } \\
\text { Test } \\
\end{array}$} \\
\hline & Range & Median & $\begin{array}{c}\text { Interquartile } \\
\text { Range }\end{array}$ & $\begin{array}{l}\text { Mean } \\
\text { Rank }\end{array}$ & $\mathbf{X}^{2}$ & P-value \\
\hline "Underweight & $2 \times 10^{7}-1 \times 10^{10}$ & $4 \times 10^{7}$ & $3.8 \times 10^{8}$ & 18.09 & \multirow{5}{*}{43.067} & \multirow{5}{*}{$<0.001 *$} \\
\hline Normal & $5 \times 10^{7}-1 \times 10^{11}$ & $3.95 \times 10^{9}$ & $2.05 \times 10^{10}$ & 51.02 & & \\
\hline Overweight & $6.3 \times 10^{6}-8.4 \times 10^{10}$ & $7.7 \times 10^{9}$ & $9.50 \times 10^{9}$ & 56.46 & & \\
\hline Obese & $2.4 \times 10^{8}-1.33 \times 10^{11}$ & $2.4 \times 10^{10}$ & $5.82 \times 10^{10}$ & 73.43 & & \\
\hline $\begin{array}{l}\text { Morbid } \\
\text { obesity }\end{array}$ & $2 \times 10^{8}-2.6 \times 10^{10}$ & $9.5 \times 10^{9}$ & $1.59 \times 10^{10}$ & 56.33 & & \\
\hline
\end{tabular}


Fig.1 Correlation between faecal Lactobacilli (VBC) and (BMI)

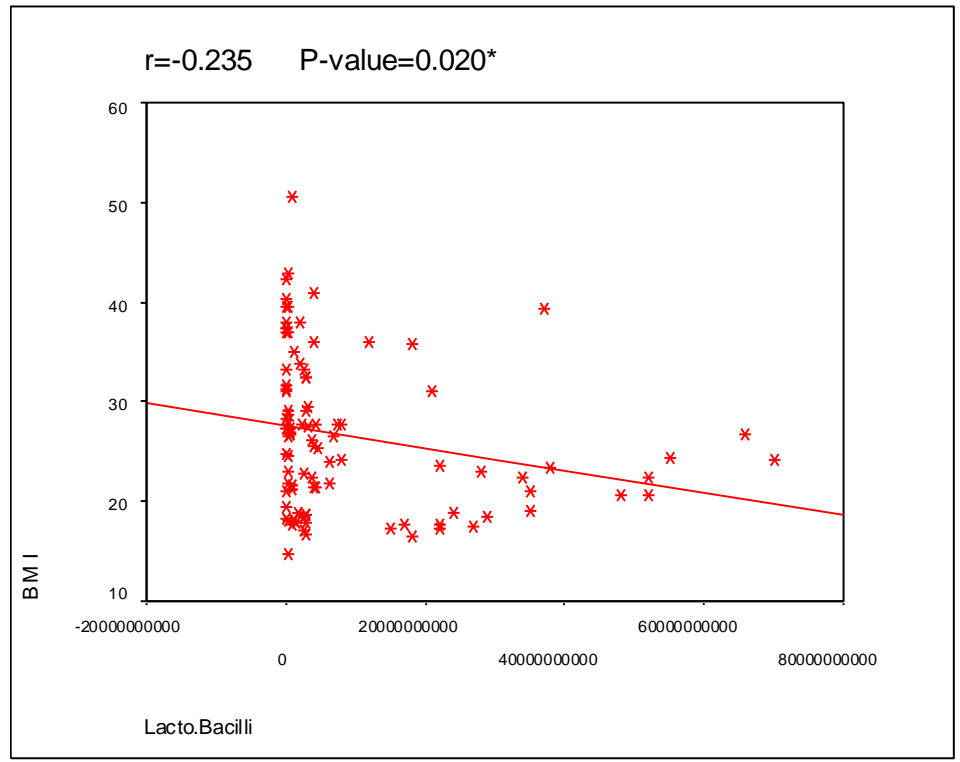

Fig.2 Correlation between faecal E. coli (VBC) and BMI

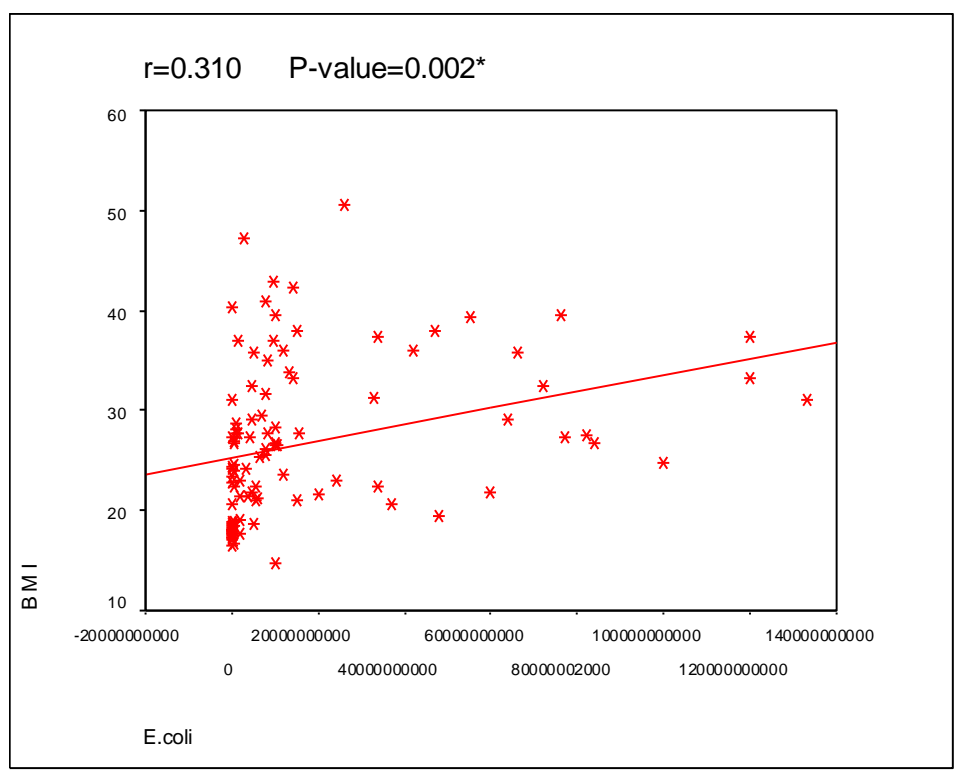

The limitation of this study was the extremes of BMI (morbid obesity and underweight individuals) which necessitates the increase of samples size in further studies, to avoid outliers. In addition, S. aureus couldn't be detected in this study despite its positive correlation with obesity as Santacruz et al., (2010) found that the increase of $S$. aureus numbers were related to cases with increased plasma cholesterol levels which were excluded in this study. Also, the anaerobic profile needs to be assed and correlated to identify its role in disturbed body mass index.

In conclusion, Low Lactobacilli $\mathrm{VBC}$ and high $E$. coli $\mathrm{VBC}$ are significantly related to increased BMI and thus obesity, while, high Lactobacilli VBC is significantly related to average weight individuals. 
This research recommends the identification of gut microbiota to the species level on a large scale of individuals to evaluate their distribution in obese persons and evaluate the significance of the use of certain strains of Lactobacilli as a probiotic as an adjuvant therapy for obesity.

\section{Acknowledgement}

We thank all the volunteers because without their contribution, this study would not have been completed.

\section{References}

Armougom, F., Henry, M., Vialettes, B., Raccah, D., and Raoult, D. 2006. Monitoring bacterial community of human gut microbiota reveals an increase in Lactobacillus in obese patients and Methanogens in anorexic patients. PLoS One, 4(9): e7125.

Angelakis, E., Armougom, F., Million, M., and Raoult, D. 2012. The relationship between gut microbiota and weight gain in humans. Future Microbiol., 7: 91109.

Bäckhed, F., Ding, H., Wang, T., Hooper, L.V., Koh, G.Y., Nagy, A., Semenkovich, C., and Gordon, J. 2004. The gut microbiota as an environmental factor that regulates fat storage. Proc. Natl. Acad. Sci., 101: 15718-15723.

Cani, P.D., Bibiloni, R., Knauf, C., Waget, A., Neyrinck, A.M., Delzenne, N.M., and Burcelin, R. 2008. Changes in gut microbiota control metabolic endotoxemia-induced inflammation in high-fat diet-induced obesity and diabetes in mice. Diabetes, 57: 1470 1481.

Chiu, C.M., Huang, W.C., Weng, S.L., Tseng, H.C., Liang, C., Wang, W.C., Yang, T., Yang, T.L., Weng, C.T., Chang, T.H., and Huang, H.D. 2014. Systematic
Analysis of the Association between Gut Flora and Obesity through HighThroughput Sequencing and Bioinformatics Approaches; BioMed Res. Int., $10 \mathrm{Pp}$.

Ignacio, A., Fernandes, M.R., Rodrigues, V.A., Groppo, F.C., Cardoso, A.L., Avila-Campos, M.J., and Nakano, V. 2016. Correlation between body mass index and faecal microbiota from children. Clin. Microbiol. Infect., 22: 258.e1-258.e8.

Karlsson, C.L., Molin, G., Fåk, F., Johansson, Hagslätt, M.L., Jakesevic, M., Håkansson, Å., Jeppsson B, Weström B, and Ahrné, S. 2011. Effects on weight gain and gut microbiota in rats given bacterial supplements and a highenergy-dense diet from fetal life through to 6 months of age. Br. J. Nutr., 106(6): 887-895.

Ley, R.E., Bäckhed, F., Turnbaugh, P., Lozupone, C.A., Knight, R.D., and Gordon, J.I. 2005. Obesity alters gut microbial ecology. Proc. Natl. Acad. Sci. U S A, 102, 11070-11075.

Ley, R.E., Turnbaugh, P.J., Klein, S., and Gordon, J.I. 2006. Microbialecology: human gut microbes associated with obesity. Nature, 444, 1022-1023.

Million, M., Angelakis, E., Maraninchi, M., Henry, M., Giorgi, R., Valero, R., Vialettes, B. and Raoult, D. 2013. Correlation between body mass index and gut concentrations of Lactobacillus reuteri Bifidobacterium animals, Methanobrevibactersimithii and Escherichia coli. Int. J. Obesity, 37(11): 1460-1466.

Million, M., Maraninchi, M., Henry, M., Armougom, F., Richet, H., Carrieri, P., Valero, R., Raccah, D., Vialettes, B., and Raoult, D. 2012. Obesity-associated gut microbiota is enriched in Lactobacillus reuteri and depleted in Bifidobacterium animalis and 
Methanobrevi bactersmithii. Int. $J$. Obesity, 36: 817-825.

Musso, G., Gambino, R., and Cassader, M. 2011. Interactions between gut microbiotaand host metabolism predisposing to obesity and diabetes. Annu. Rev. Med., 63: 361-380.

Santacruz, A., Collado, M.C., Gracia-Valdes, L., Segura, M.T., Martín-Lagos, J.A., Anjos, T., Martí-Romero, M., Lopez, R.M., Florido, J., Campoyand, C., Sanz, Y. 2010. Gut microbiota composition is associated with body weight, weight gain and biochemical parameters in pregnant women. British J. Nutri., 104: 83-92.

Sepp, E., Lo ivukene, K., Julge, K., Voor, T., and Mikelsaar, M. 2013. The association of gut microbiota with body weight and body mass index inpreschool children of Estonia. Microbial. Ecol. Health \& Dis., 24: 19231.

Sharma, N., Chaudhry, R., and Panigrah, P. 2012. Quantitative and Qualitative Study of Intestinal Flora in Neonates, $J$. Glob. Infect. Dis., 4(4): 188-192.

Sieuwerts, S., de Bok, F.A., Mols, E., de vos, W.M., and Vlieg, J.E. 2008. A simple and fast method for determining colony forming units. Lett. Appl. Microbiol., 47(4): 275-278.

Turnbaugh, P.J., Hamady, M., Yatsunenko, T., Cantarel, B.L., Duncan, A., Ley, R.E., Sogin, M.L., Jones, W.J., Roe, B.A., Affourtit, J.P., Egholm, M., Henrissat, B., Heath, A.C., Knight, R., and Gordon, J.I. 2009. A core gut microbiome in obese and lean twins. Nature, 457: 480-484.

Whitlock, G., Lewington, S., Sherliker, P., Clarke, R., Emberson, J., Halsey, J., Qizilbash, N., Collins, R., and Peto, R. 2009. Body mass index and cause specific mortality in 900000 adults: collaborative analyses of 57 prospective studies. Lancet, 373: 1083-1096.

Xiao, S., Fei, N., Pang, X., Shen, J., Wang, L., Zhang, B., Zhang, M., Zhang, X., Zhang, C., Li, M., Sun, L., Xue, Z., Wang, J., Feng, J., Yan, F., Zhao, N., Liu, J., Long, W., and Zhao, L. 2014. A gut microbiota-targeted dietary intervention for amelioration of chronic inflammation underlying metabolic syndrome. FEMS Microbiol Ecol., 87(2): 357-367.

\section{How to cite this article:}

Sally M. Saber, Hala B. Othman, Sherin ElMasry, Alaa Magdyand, Howayda F. Zidan. 2017. Correlation between Body Mass Index and Gut Microbiota in Adults. Int.J.Curr.Microbiol.App.Sci. 6(2): 778-787. doi: http://dx.doi.org/10.20546/ijcmas.2017.602.086 